\title{
Influenza A Virus and Influenza B Virus Can Induce Apoptosis via Intrinsic or Extrinsic Pathways and Also via NF- $\kappa$ B in a Time and Dose Dependent Manner
}

\author{
Ibrahim El-Sayed, ${ }^{1}$ Khalid Bassiouny, ${ }^{1}$ Aziz Nokaly, ${ }^{2}$ \\ Ahmed S. Abdelghani, ${ }^{3}$ and Wael Roshdy ${ }^{3}$ \\ ${ }^{1}$ Genetic Engineering and Biotechnology Research Institute (GEBRI), University of Sadat City, Sadat City 32897, Egypt \\ ${ }^{2}$ Faculty of Medicine, Al-Azhar University, Cairo 35527, Egypt \\ ${ }^{3}$ Central Public Health Laboratories (CPHL), Cairo 11613, Egypt \\ Correspondence should be addressed to Wael Roshdy; waelhamedroshdy@yahoo.com
}

Received 28 October 2015; Accepted 7 February 2016

Academic Editor: Andrei Surguchov

Copyright ( $) 2016$ Ibrahim El-Sayed et al. This is an open access article distributed under the Creative Commons Attribution License, which permits unrestricted use, distribution, and reproduction in any medium, provided the original work is properly cited.

Influenza viruses are able to cause annual epidemics and pandemics due to their mutation rates and reassortment capabilities leading to antigenic shifts and drifts. To identify host response to influenza A and B viruses on A549 and MDCK II cells at low and high MOIs, expressions of MxA and caspases 3, 8, and 9 and $\mathrm{BAD}, \mathrm{TNF} \alpha$, and $\mathrm{I} \kappa \mathrm{B} \alpha$ genes were measured in the cells supernatants. H1N1 and $\mathrm{H} 3 \mathrm{~N} 2$ prefer to initially enhance the intrinsic pathway, determined by higher caspase 9 activity in MDCK II cells compared to caspase 8 activity and vice versa in A549 cells at different MOIs, while INF B prefers extrinsic pathway in A549 cells according to significant low or undetectable caspase 9 activity and high activity of caspase 8 but also can induce intrinsic pathway in MDCK II cells as determined by significant low or undetectable activity of caspase 8 and high caspase 9 activity at different MOIs; the considerable MxA expression was found in influenza A and B viruses infected A549 and MDCK II cells at low MOIs. In conclusion, influenza A and B viruses induced extrinsic and intrinsic apoptosis in parallel, and the induction was associated with viral infection in a dose dependent manner.

\section{Introduction}

Influenza A virus, a major cause of morbidity and mortality in humans, is primarily a pathogen of the upper respiratory tract; its infection results in both respiratory effects and constitutional effects $[1,2]$.

Influenza viruses $\mathrm{A}$ and $\mathrm{B}$ infection induces distinct apoptosis profiles; the differential biological effects of the influenza A and B viruses have been the focus of intense research [3].

Influenza viruses are able to cause annual epidemics and pandemics due to their mutation rates and reassortment capabilities leading to antigenic drifts and antigenic shifts [46].
Influenza viruses belong to the Orthomyxoviridae family and are grouped into types (and subtypes), of which type A and $\mathrm{B}$ are the most relevant to humans $[7,8]$.

They are enveloped, negative single stranded RNA viruses with a segmented genome divided into 8 genes that code for 11 proteins [6] that not only act as viral components but also interact with the pathways of host infected cells, mainly to counteract the antiviral cell response and help the viral replication [9-11]. To date, up to 1023 interactions between viral and host proteins have already been described $[6,9]$. Apoptosis induced during influenza virus infection is a major contributing factor to cell death and tissue damage [12-15].

All of the mammalian, as well as all of the avian, influenza viruses tested induce apoptosis in MDCK cells, which prove that apoptosis is a general mechanism by which influenza 
viruses kill cells and, therefore, that these viruses can be blocked by cellular inhibitors of apoptosis [12].

Studies with the 1918 pandemic virus in macaques showed that activation of the apoptotic pathway was a source of tissue damage during infection [16-18].

In mammalian cells, the apoptotic pathway can be divided into two signaling cascades: the extrinsic and the intrinsic apoptotic pathways [19].

The intrinsic apoptotic pathway acts through the mitochondria upon activation, and this signaling process is highly regulated by the Bcl-2 family of proteins, which consists of both antiapoptotic and proapoptotic members that form a critical decision point within a common cell death signaling pathway [20].

The delicate balance between antiapoptotic and proapoptotic protein activities dictates whether a cell will succumb to an apoptotic stimulus or not [21,22].

Despite the increasing knowledge in the influenza virus host interactions, most of the published work focuses on influenza A viruses, leaving a gap with respect to influenza $\mathrm{B}$ virus host interactions $[5,23]$.

H3N2 viruses with high NA activities induced high levels of apoptosis (83-94\%) and infected $91-98 \%$ of cells, while H1N1 viruses with low NA activities were poor apoptosis inducers (11-19\%) and infected few (15-21\%) cells. The differences in \% infected cells reflected differences in haemagglutinin (HA) receptor binding affinity [24].

$\mathrm{Bcl}-2$ and $\mathrm{Bcl}-\mathrm{xL}$ are well-known targets of the proapoptotic protein Bcl-2 antagonist of cell death (BAD), which specifically blocks the activity of both antiapoptotic factors $\mathrm{z}$ by forming heterodimeric complexes with either of the two proteins and displacing Bax [15-26].

One of its downstream targets is the I $\kappa \mathrm{B}$ kinase (IKK), which once engaged leads to the activation of the transcription factor NF- $\kappa \mathrm{B}$. In fact, under resting conditions, NF- $\kappa \mathrm{B}$ is sequestered in the cytoplasm through interaction with $\mathrm{I} \kappa \mathrm{B}$ protein that prevents NF- $\kappa$ B from entering the nucleus [27].

NF- $\kappa$ B is sensitive proinflammatory miRNA with a relatively short half-life of about $2 \mathrm{~h}$ in the human CNS $[23,28]$.

Following NF- $\kappa \mathrm{B}$ activating stimuli, IKK is activated and phosphorylates $\mathrm{I} \kappa \mathrm{B}$, thus promoting nuclear translocation of NF- $\kappa \mathrm{B}$ to induce transcriptional activation of survival proteins, including $\mathrm{Bcl}-\mathrm{XL}, \mathrm{Bcl}-2$, and $\mathrm{X}$-linked inhibitor of apoptosis protein (XIAP) $[29,30]$.

Importantly NF- $\kappa \mathrm{B}$ activation is usually terminated via $\mathrm{I} \kappa \mathrm{B}$ protein resynthesis and NF- $\kappa \mathrm{B}$ reinhibition [28-32].

From the multiple domains of NS1 of influenza A virus (NS1A) only one, the $\mathrm{N}$ terminal binding double stranded RNA domain, has been shown to be shared with the NS1 protein of influenza B virus (NS1B) [33].

Considering that the manipulation of apoptosis induction during influenza virus infection is partly associated with a motif of NS1A protein, with no homologous function in NS1B protein, we proposed the apoptotic pathways that could be differently affected by influenza A (both strains) and B viruses.

\section{Materials and Methods}

2.1. Cells. The IFN-competent human cells include alveolar epithelial cell line A549 and were obtained from central public health laboratories in Egypt (CPHL), Madin-Darby canine kidney cells (MDCK II), European Collection of Cell Cultures (ECACC), London, UK, recommended by World Health Organization for influenza virus replication and were obtained from central public health laboratories in Egypt (CPHL), and were kept in maintenance medium containing Dulbecco's Modified Eagle Medium, (DMEM; Gibco, Paisley, UK), 2 mM l-Glutamine (Gibco), 1× NEAA (Nonessential Amino Acids, Gibco), and $24 \mathrm{mM}$ HEPES (N-2hydroxyethylpiperazine-N-2-ethane sulfonic acid, Gibco) at $30^{\circ} \mathrm{C}$. MDCK II cells were subcultured at $3-4 \times 10^{4}$ cells $/ \mathrm{cm}^{2}$ with growth medium maintenance medium supplemented with $10 \%$ fetal bovine serum (FBS; Gibco). Growth medium was supplemented with $1 \mathrm{mg} / \mathrm{mL}$ Geneticin ${ }^{\circledR}$ (Gibco) for cell line continuation or with $2.5 \mu \mathrm{g} / \mathrm{mL}$ Fungizone ${ }^{\circledR}$ (Gibco) and $1 \times$ PSN (Penicillin-Streptomycin-Neomycin Antibiotic Mixture, Gibco) when cells were plated to be infected. Cultures were incubated at $37^{\circ} \mathrm{C}$ for $48 \mathrm{~h}$ prior to infection to reach a minimum of $90 \%$ monolayer confluence.

2.2. Viruses. Influenza A (subtype A (H1N1) pdm09) (isolated in CPHL in Egypt) and influenza A (subtype A (H3N2) isolated in CPHL in Egypt) and influenza B/Yamgata isolated in CPHL in Egypt viruses were propagated on MDCK II cells for stock constitution. Briefly, MDCK II cells in monolayer were infected with the virus and left to stand for $30 \mathrm{~min}$ for virus adsorption as controls.

Monolayer of the cells at a concentration of $1 \times$ $10^{6}$ cells $/ \mathrm{mL}$ was infected with the virus at a multiplicity of infection (MOI) of 0.1 and 1.0 PFU/cell in the presence of supplemental trypsin. Following adsorption for $1 \mathrm{~h}$ at $37^{\circ} \mathrm{C}$, the inoculum was removed and washed before DMEM replaced.

The cultures were incubated up to 48 hours postinfection (hpi) and observed by inverted light microscopy for cytopathic effect (CPE). For each cell, four different sets of tissue culture flask were infected. Mock infected cells served were titrated before and after infection as described previously [34].

2.3. Cell Viability Assay. A549 and MDCK cells were infected by $\mathrm{H} 3 \mathrm{~N} 2, \mathrm{H} 1 \mathrm{~N} 1 \mathrm{PDM} 09$, and influenza $\mathrm{B}$ virus at MOI of 0.1 and 1.0 PFU/cell and culture supernatants obtained at $8 \mathrm{~h}$ intervals up to $48 \mathrm{hpi}$. Cell viability following viral infection was determined by 3-(4, 5-dimethylthiazol-2-yl)-2, 5-diphenyl tetrazolium bromide (MTT) assay.

In this case, each cell was seeded in 96-well culture plates (approximately 5,000 cells per well) incubated with the related culture supernatants. The cells were washed with PBS and incubated with DMEM and $50 \mu \mathrm{L} /$ well of MTT solution $(5 \mathrm{mg} / \mathrm{mL})$ for another $3 \mathrm{~h}$ at $37^{\circ} \mathrm{C}$. Then, the medium was totally removed, and $200 \mu \mathrm{L}$ of $0.04 \mathrm{~N} \mathrm{HCl}$ in isopropanol was added to each well, and the plate was incubated for $1 \mathrm{~h}$ at room temperature. Optical density value was measured at $540 \mathrm{~nm}$ using an ELISA reader. 
Cell survival was expressed as the ratio of virus infected to uninfected control. The three independent experiments were performed.

2.4. LDH Assay. The media of infected cells were removed from each condition at $8,24,36$, and $48 \mathrm{~h}$ postinfection (hpi) and centrifuged at $250 \times \mathrm{g}$ for $4 \mathrm{~min}$. Total cell death was determined by measuring the release of $\mathrm{LDH}$ from cells with the CytoTox96 ${ }^{\circledR}$ Nonradioactive Cytotoxicity Assay kit (Promega, Madison, IL, USA), according to the manufacturer's instructions. The cell monolayer was recovered for morphological analyses of apoptosis [35].

2.5. DNA Fragmentation. Cell death was evaluated by fragmentation of genomic DNA. Samples of virus infected cells were centrifuged, and the cell pellet was resuspended in $300 \mathrm{~mL}$ of cold cell lysis buffer (10 mM Tris, $0.5 \%$ Triton X100 ( $\mathrm{pH} \mathrm{7.5))} \mathrm{and} \mathrm{then} \mathrm{incubated} \mathrm{on} \mathrm{ice} \mathrm{for} 30 \mathrm{~min}$. The lysates were centrifuged at $12,000 \mathrm{rpm}$ for $10 \mathrm{~min}$ at $4^{\circ} \mathrm{C}$, and the supernatants were extracted once with buffered phenol and once with chloroform.

The DNA was precipitated with $300 \mathrm{mM} \mathrm{NaCl}$ and ethanol. DNA samples were resuspended in $50 \mu \mathrm{L}$ of TrisEDTA buffer (10 mM Tris, 1 mM EDTA (pH 7.5)) treated with RNase A. The extracted DNAs were electrophoresed through a $2 \%$ agarose gel and stained with ethidium bromide.

2.6. Fluorescent Microscopy. The mock and infected cells were washed twice with PBS and fixed with $4 \%$ paraformaldehyde before being stained with anti-mouse IgG: FITC conjugate to each $(1 \mathrm{mg} / \mathrm{mL})$ for $30 \mathrm{~min}$ at $37^{\circ} \mathrm{C}$. Stained cells were observed with a fluorescence microscope (Olympus BX51).

2.7. Real-Time RT PCR Analysis. Total RNA was extracted from cells using Qiagen according to the manufacturer's protocol. Five hundred nanograms of purified mRNA was used to generate cDNA with random hexamer primers (Thermo Scientific) and Revert Aid H Minus M-MuL V Reverse Transcriptase (Thermo Scientific) according to the manufacturer's protocol.

The quantitative real-time PCR (qRT-PCR) reaction mixture $(25 \mu \mathrm{L})$ consisted of the following: $12.5 \mu \mathrm{L}$ of Maxima SYBR green PCR master mix (Thermo Scientific), $0.5 \mu \mathrm{L}$ of cDNA template, and $1 \mu \mathrm{L}$ of each primer $(100 \mu \mathrm{M}$ forward and reverse primers) (Table 1). Reactions were run in duplicate on Applied Biosystems 7500 real-time PCR system. The cycling conditions were as follows: $2 \mathrm{~min}$ at $50^{\circ} \mathrm{C}, 2 \mathrm{~min}$ at $95^{\circ} \mathrm{C}$, and 50 cycles, with 1 cycle consisting of $15 \mathrm{~s}$ at $95^{\circ} \mathrm{C}$ and $30 \mathrm{~s}$ at $60^{\circ} \mathrm{C}$. Threshold cycle $(\mathrm{Ct})$ values were normalized to the values for the GAPDH control and compared with $\beta$-actin controls primers for real-time PCR of RNA transcripts.

\section{Results}

To study the cytopathogenicity effect of the studied cells to Flu A/Pdm H1N1 09, Flu A/H3N2, and Flu B/Yamagata viruses, A549 and MDCK II cells were infected at MOI 0.1 and 1.0, although the marked CPEs were evident at $16 \mathrm{hpi}$ for A549 cells infected with Flu B and H1N1 at higher MOI 1.0 which increased with time. At $24 \mathrm{hpi}$ approximately half of the infected cells appeared smaller and irregularly shaped compared to mock cells. All studied influenza virus strains did not affect the CPE at MOI 0.1 on A549 cells (Figure 1). Infection of MDCK II cells with Flu B and $\mathrm{H} 1 \mathrm{~N} 1$ viruses caused a fast CPE especially at MOI 1.0 and a rapid fall in $\mathrm{pH}$ of cell suspension.

The granular and fragmented cells became obvious within 24 to $48 \mathrm{hpi}$. The infectious viruses were titrated by plaque assay at 16, 24, and $48 \mathrm{hpi}$. Higher viral titers were observed in infected A549 cells, and the peak of titer reached $48 \mathrm{hpi}$; however, statistical differences were not observed between MDCK II and A549 cells at MOI 1.0. The mean peak titers of the INF B virus in these cells reached 4.3 and $4.4 \mathrm{PFU} / \mathrm{mL}$, respectively. The mean peak titers of the $\mathrm{H} 3 \mathrm{~N} 2$ virus in these cells reached 2.0 and $2.1 \mathrm{PFU} / \mathrm{mL}$, respectively, until $48 \mathrm{hpi}$ at both MOIs.

In addition, development of countable plaques required more days of incubation for $\mathrm{H} 3 \mathrm{~N} 2$ compared to other viruses.

The detection of lactate dehydrogenase (LDH) can be used to evaluate efficiently anti-influenza viruses' agents. LDH levels in the virus infected MDCK II and A549 cells were significantly higher than in controls, were in proportion to the degree of virus infection, and corresponded to a decrease in mitochondrial dehydrogenase activity.

LDH cytotoxicity assays were performed with different MOI of $\mathrm{H} 3 \mathrm{~N} 2$, Flu $\mathrm{B}$, and $\mathrm{H} 1 \mathrm{~N} 1$ viruses at $8 \mathrm{~h}$ interval exposure times in A549 and MDCK II cells (Figures 4(a) and $4(\mathrm{~b}))$.

Induction of general cell death in Flu A/Pdm H1N1 09, Flu A/H3N2, and Flu B/Yamagata infection differs in time and intensity. While cell death induced by INF B occurred earlier in infection, at $24 \mathrm{~h}$ postinfection (hpi) $(p<0.05)$, compared to $\mathrm{H} 1 \mathrm{~N} 1$ and $\mathrm{H} 3 \mathrm{~N} 2$ infection mediated cell death that occurs after $32 \mathrm{hpi}$ (Figures $4(\mathrm{a})$ and $4(\mathrm{~b})$ ) in both cell lines. The infected A549 and MDCK II cells at higher MOI showed significantly cell death confirming the DNA fragmentation and nuclear condensation results. Regarding intensity of cell death induced by infection, H1N1 was shown to be more virulent, reaching a maximum of 4-fold increased cell death at $48 \mathrm{hpi}$ in MDCK II cells and up to 5-fold in A549 cells, compared with mock infection $(p<0.01)$; exposure to INF B virus was shown to be less toxic to cells, and the cell viability was decreased with the increase in virus MOI in A549 and MDCK II cells, compared with mock and infected cells at MOI 1.0. Thus, these results suggest that LDH release and apoptosis start earlier, but with lower intensity, in cells infected with INF B than with H1N1 and H3N2, respectively (Figures 4(a) and 4(b)). A detectable DNA laddering in the virus infected cells appeared by $16 \mathrm{hpi}$ at MOI 1.0 (Figure 3(b)). This pattern significantly progressed at $48 \mathrm{hpi}$.

The INF B infected A549 cells demonstrated nuclear condensation, which can be detected by FITC staining, as shown in Figure 3(a).

The infected A549 cells undergoing apoptosis exhibited some cells with fragmented nuclei. The virus mainly caused 
Results:
A549

Mock 24 hpi MOI (0.1) 48 hpi MOI (0.1)
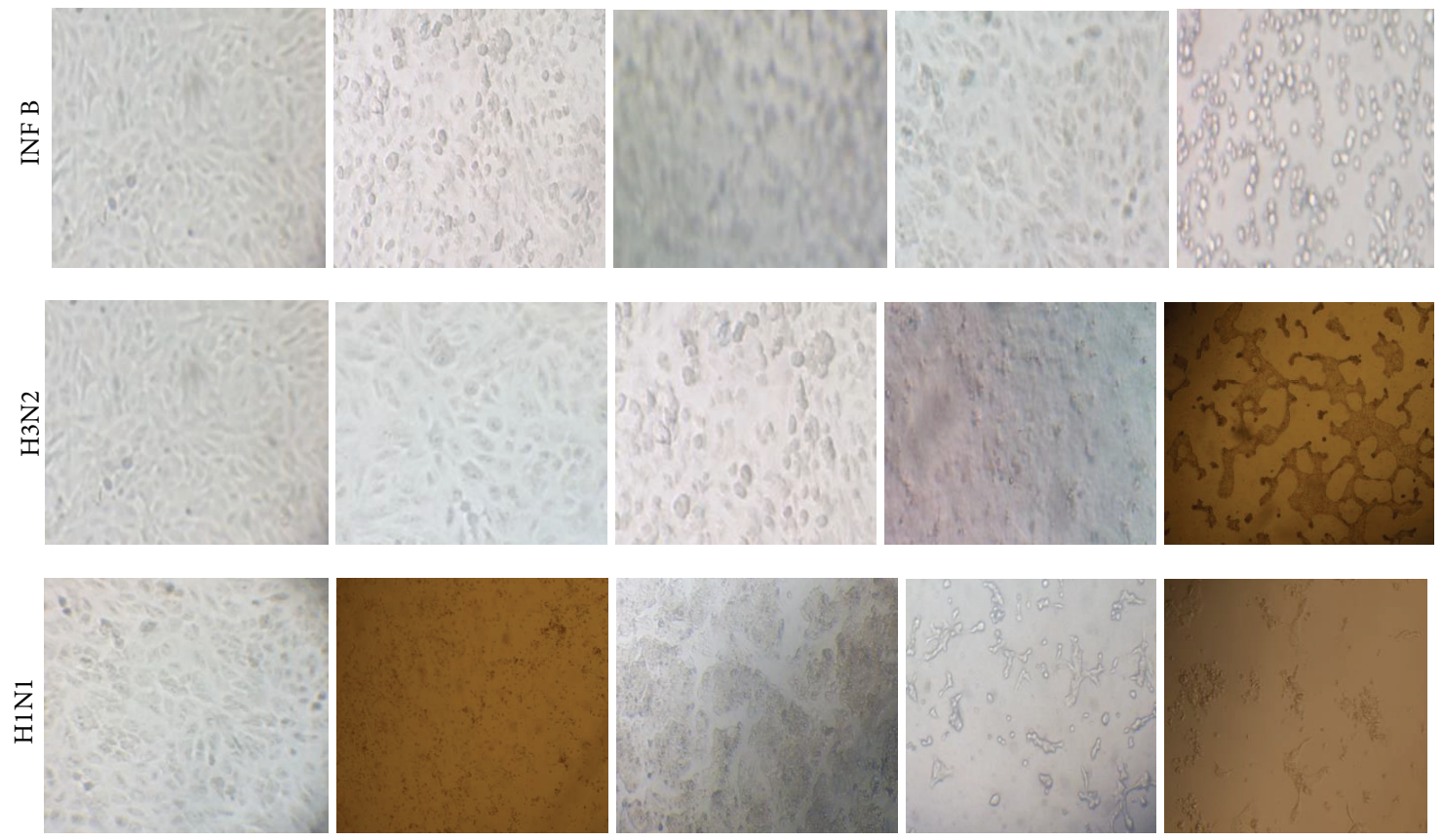

FIGURE 1: Cytopathogenicity of A549 cells to an influenza A and B viruses infection at 24 and 48 hours after infection (10x magnification).

cell death in MDCK II cells; therefore, it seems that H3N2, INF B, and H1N1 virus induced apoptosis in A549 cells in dose and time dependent manner (Figures 1 and 2(a)).

To determine whether the death receptor or mitochondrial pathways modulated apoptosis, samples from the infected cells were analyzed for the levels of expressions of proapoptotic marker bad and caspase 3 , caspase 8 , and caspase 9 using quantitative RT-PCR (Table 1).

The presence of a significance increase in the tested markers compared to mock and nonapoptotic cells indicating low level or undetectable tested markers in these cells (Tables 2,3 , and 4 ).

A dose and time dependent activation of caspase 3, caspase 8, and caspase 9 proteins was observed in H3N2, INF B, and H1N1 infected A549 and MDCK II cells (Tables 2, 3, and 4).

The levels of caspase 8 protein activation were not detected in INF B infected MDCK II cells (Table 3); however, the cell viability was significantly lower in MDCK II than A549-infected cells (Figure 2).

The apoptotic markers in A549 and MDCK II cells were evaluated by quantitative RT-PCR (Table 1).

However, different regulation levels of MxA mRNA were observed in A549 and MDCK II cells infected by H1N1, $\mathrm{H} 3 \mathrm{~N} 2$, and INF B, and expression of MxA gene was upregulated at $16 \mathrm{hpi}$ which reached to maximal level at $24 \mathrm{hpi}$ compared with mock cells; however, the higher dose of virus is, a weaker MxA expression was detected (Tables 2, 3, and 4).
MxA expression showed similar pattern of induction peaking on $24 \mathrm{hpi}$ and decreasing by $48 \mathrm{hpi}$ in MDCK II cells at both infectious doses in all studied influenza subtypes (Tables 2, 3, and 4).

MxA mRNA expression for A549 cells was very high in response to INF B infection compared to H1N1 and H3N2 infection. However, it is same order in MDCK II infected cell but with lower response than A549 infected cell (Tables 2, 3, and 4).

3.1. The Delayed Onset of Cytopathogenicity by H3N2. Influenza H3N2 virus infected A549 cells also elicited less TNF alpha and FasR transcription than either INF B or H1N1. These observations can account for the lower apoptotic response in influenza H3N2 virus infected lung (Figure 2(b)). As little impact on the expression of intrinsic pathway components was observed, it seems that the apoptotic response to influenza virus infection in A549 cells was mainly through the extrinsic pathways (Table 2).

The delayed onset of cytopathogenicity by H3N2 may take more than 96 hpi to obtain clear cytopathogenic effect compared to INF B or H1N1 Figure 2(b).

In addition, the pattern observed for general cell death seems to correlate with that observed for apoptosis, in all studied influenza subtypes.

To evaluate potential differences of apoptotic signaling pathways triggered by influenza $A$ and $B$ viruses infection, we measured the activity of several caspases, such as the effector 

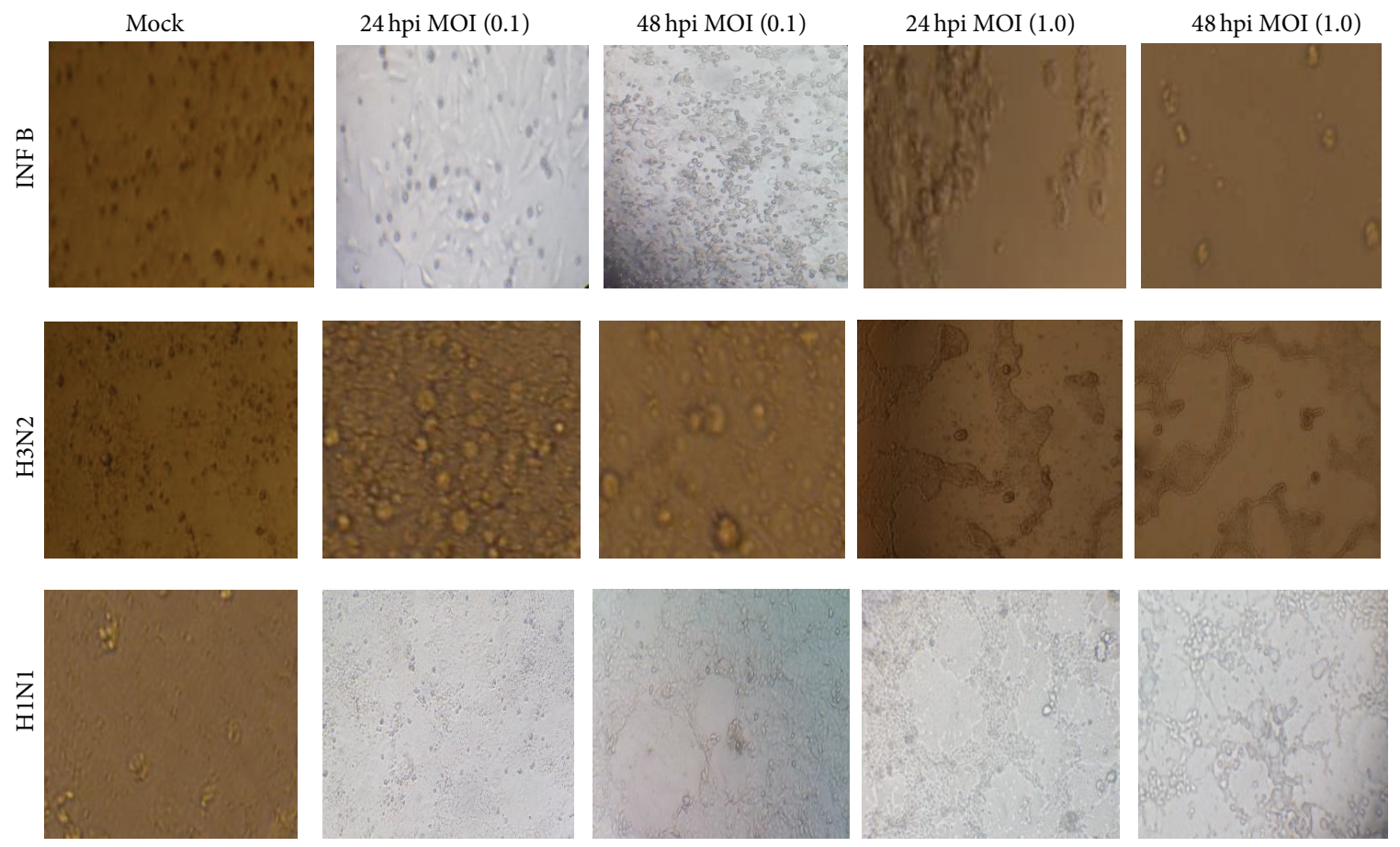

(a) MDCK II
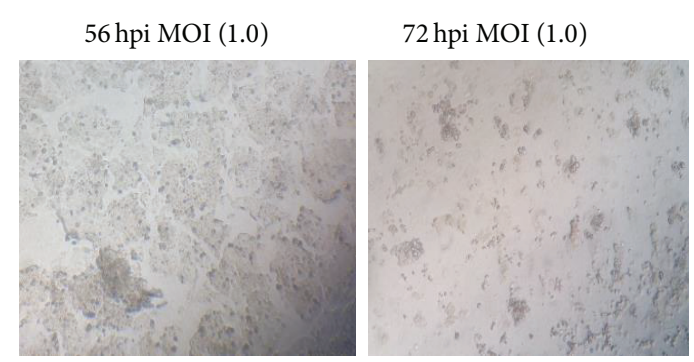

96 hpi MOI (1.0)

120 hpi MOI (1.0)
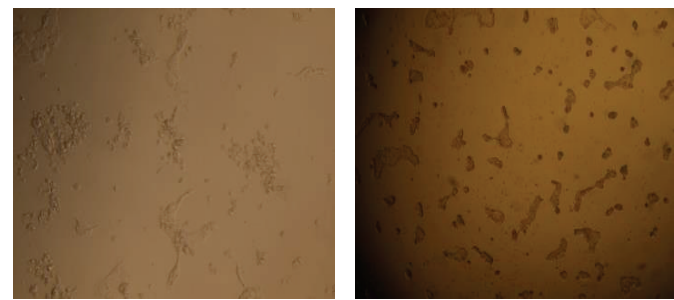

(b) $\mathrm{H} 3 \mathrm{~N} 2$

Figure 2: (a) Cytopathogenicity of MDCK II cells to an influenza A and B viruses infection at 24 and 48 hours after infection. (b) The delayed onset of cytopathogenicity by H3N2 (10x magnification).

caspase 3, the extrinsic pathway associated initiator caspase 8 , and the intrinsic pathway associated initiator caspase 9.

Results show that $\mathrm{H} 1 \mathrm{~N} 1$ and $\mathrm{H} 3 \mathrm{~N} 2$ infection induced caspase 3 activities from 16 to $48 \mathrm{hpi}$, respectively (Tables 2 and 4). In addition, the activity of effector caspases increased from 16 hpi with INF B (Table 3), remaining higher than H1N1 and H3N2, respectively, infected cells, and it is seen clear in A549 cells than MDCK II cells, until 48 hpi. In fact, this early effect of INF B in inducing the activity of effector caspases, when compared with H1N1 and H3N2, respectively, corroborates the previously observed apoptotic patterns (Tables 2, 3, and 4).

The differences between $\mathrm{H} 1 \mathrm{~N} 1$ and $\mathrm{H} 3 \mathrm{~N} 2$, respectively, and INF $B$ virus mediated caspase activation were also evident for caspase 9 and caspase 8 (Tables 2, 3, and 4).

The activity of caspase 9 slightly increased in H1N1 and H3N2 infected cells, respectively, during the first $48 \mathrm{hpi}$, when compared with mock infection (Tables 2 and 4). In contrast, INF B induced lower levels of caspase 9 activity during the first $24 \mathrm{hpi}$ although persisting until $48 \mathrm{hpi}$, in MDCK II cell lines and undetectable in A549 cells (Table 3). Regarding caspase 8 , our data proved that activation of this death receptor related caspase was detected as early as $16 \mathrm{hpi}$ after INF B infection in A549 cells, where less efficiency can be detected on MDCK II cells, becoming only evident at later stages of H1N1 and H3N2 infection, respectively (Tables 2, 3, and 4).

Therefore, these results indicate that influenza H1N1 and $\mathrm{H} 3 \mathrm{~N} 2$ and INF B viruses infection mediate different apoptosis profiles.

INF B induces an immediate apoptotic response, but INF B induced cell death levels are depending on the type of cells compared to those induced by H1N1 and H3N2, respectively (Figure 4). In addition, although all virus strains 

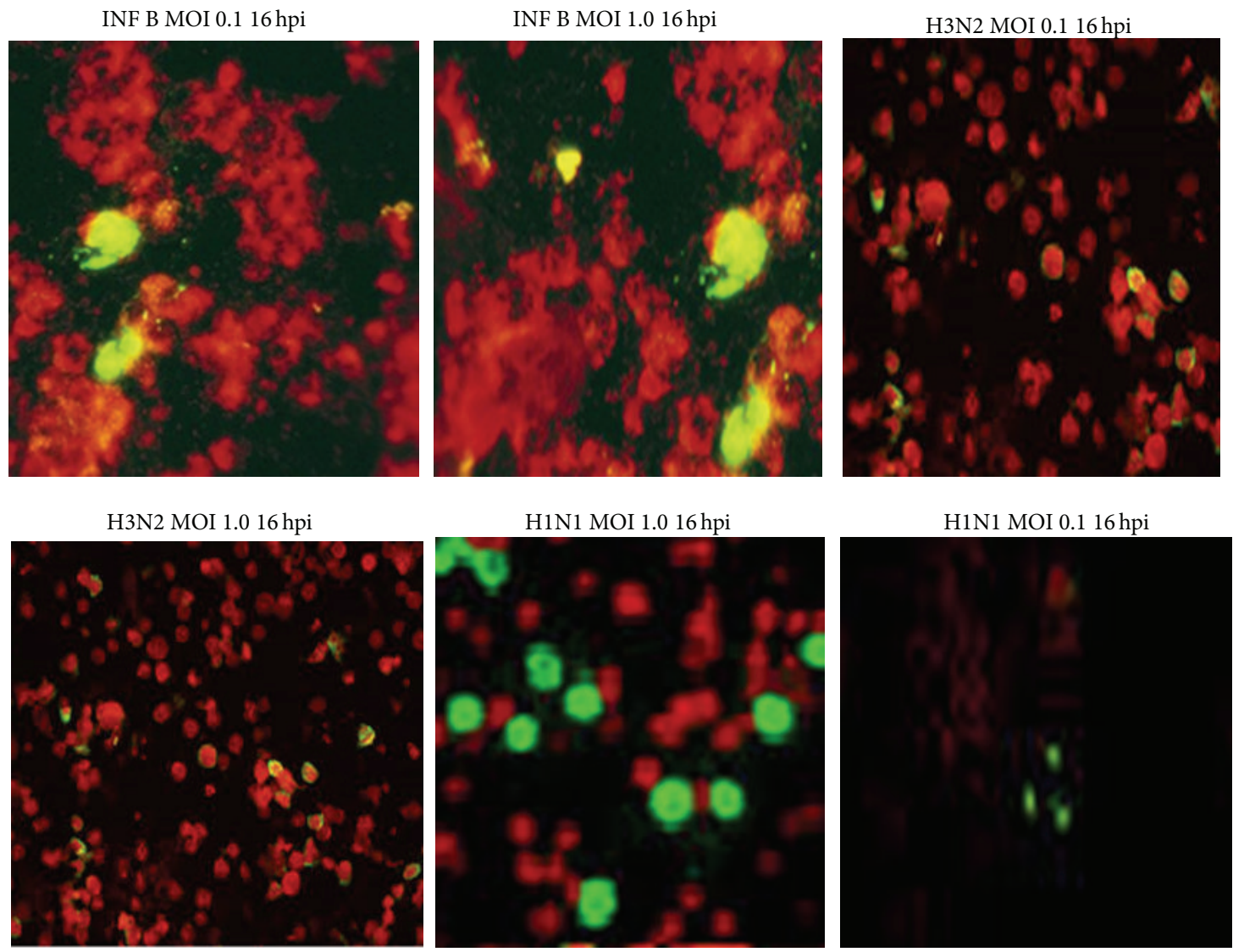

(a)
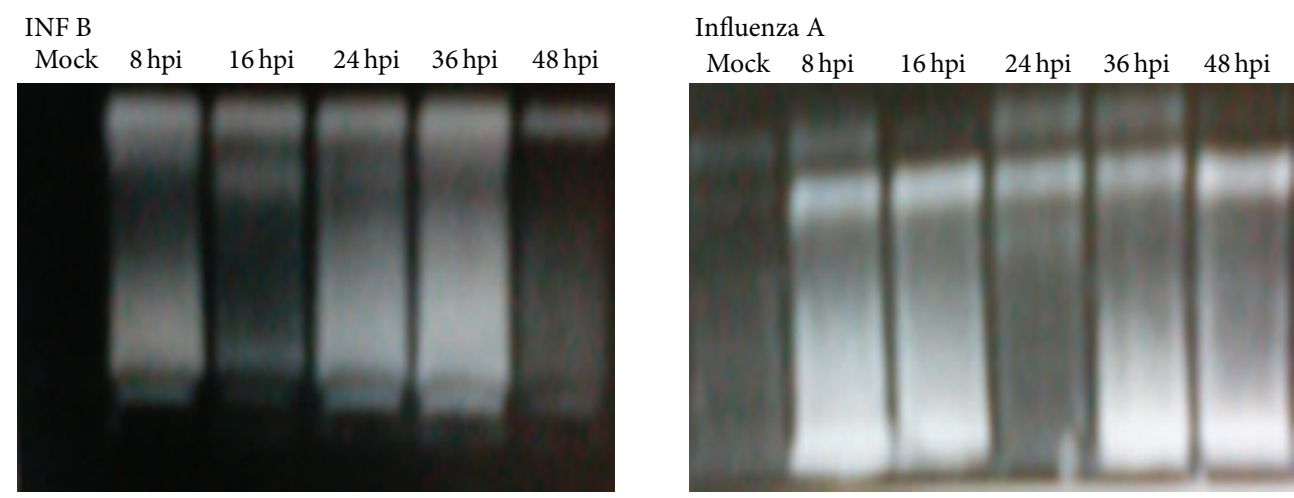

(b)

FIgURE 3: Influenza A and b viruses induce apoptosis in A549 and MDCK II cells at MOI 1.0. (a) Nuclear staining of the infected cells with FITC staining. (b) Chromosomal DNA fragmentation. DNAs were prepared from A549 cells infected with virus at $8 \mathrm{~h}$ intervals and separated by $2 \%$ agarose gel electrophoresis, followed by staining with ethidium bromide.

induced extrinsic and intrinsic apoptosis, $\mathrm{H} 1 \mathrm{~N} 1$ and $\mathrm{H} 3 \mathrm{~N} 2$, respectively, prefer to initially enhance the intrinsic pathway, as determined by caspase 9 activities and INF B prefer intrinsic pathway according to caspase 8 activity in A549 cell line but also can choose extrinsic pathway as determined by caspase 9 activity in MDCK II cells.

3.2. Influenza $A$ and $B$ Viruses Differentially Regulate NF- $\kappa B$ Activation. One of the important signaling factors for virus replication is the transcription factor NF- $\kappa \mathrm{B}$, also commonly regarded as a major regulator of the innate immune defense to infection. In fact, NF- $\kappa$ B is often activated by viruses, leading to the upregulation of a variety of antiviral genes. Several molecular mechanisms have been identified to confer this virus-supportive function of NF- $\kappa$ B. First, it was shown that NF- $\kappa B$ acts via induction of proapoptotic factors, such as TNF-related apoptosis inducing ligand (TRAIL) or FasL, and subsequent activation of caspases [36]. 


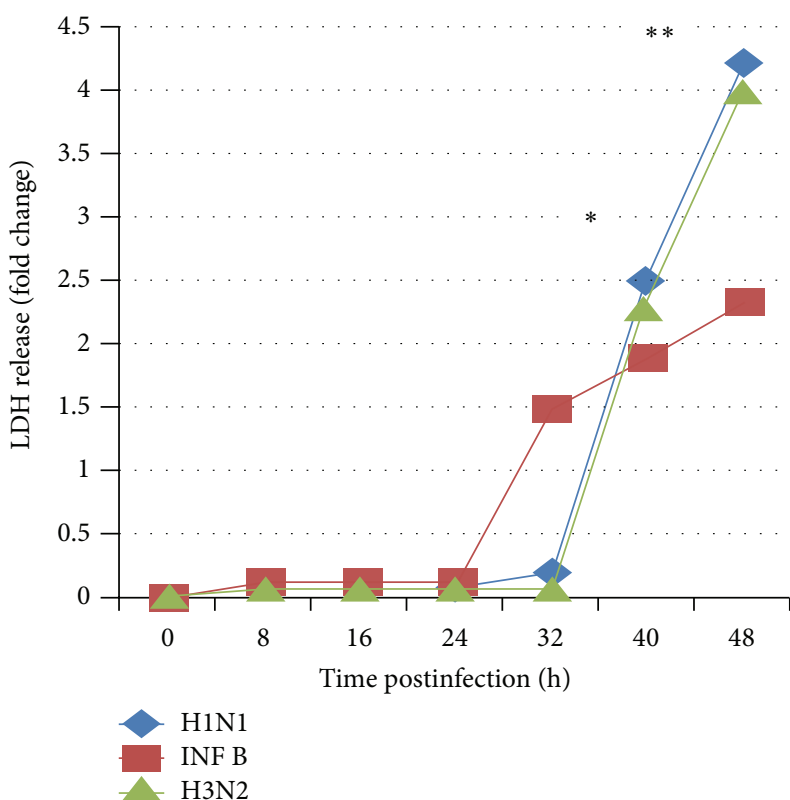

(a) MDCK II

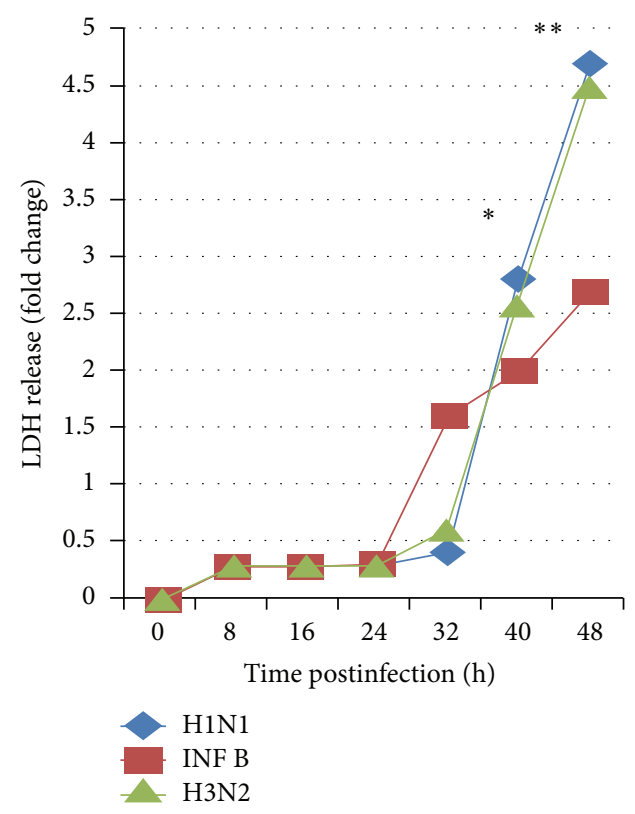

(b) A549

Figure 4: Flu A/Pdm H1N1 09, Flu A/H3N2, and Flu B/Yamagata viruses induce cell death and apoptosis profiles. Effects of influenza infection (MOI 1.0) on viability of MDCK II (a), and A549 cells (b) were determined by LDH assay. The $*$ indicates significant differences $(p<0.05$ ) and ${ }^{* *} p<0.01$ from the mock cells at the same time after infection.

TABLE 1

\begin{tabular}{|c|c|c|}
\hline Name & Direction & Sequence $5^{\prime} \rightarrow 3^{\prime}$ \\
\hline MxAF & Forward primer & TTCAGCACCTGATGGCCTATC \\
\hline MxAR & Reverse primer & TGGATGATCAAAGGGATGTGG \\
\hline b-actin & Forward primer & GAG ACC TTC AAC ACC CCG C \\
\hline b-actin & Reverse primer & ATG TCA CGC ACG ATT TCC C \\
\hline BAD & Forward primer & ACCCGGCAGACAGATGAG \\
\hline BAD & Reverse primer & CTTCСTCTCCCACCGTAGC \\
\hline $\mathrm{I} \kappa \mathrm{B}$ & Forward primer & CAGCAGACTCCACTCCACTT \\
\hline $\mathrm{I} \kappa \mathrm{B}$ & Reverse primer & GAGAGGGGTATTTCCTCGAA \\
\hline TNF- $\alpha$ & Forward primer & СТСTTCTCСTTCCTGATCGTGGCA \\
\hline TNF- $\alpha$ & Reverse primer & GTTGGATGTTCGTCCTCCTCACA \\
\hline Caspase 3 & Forward primer & TTAATAAAGGTATCCATGGAGAACACT \\
\hline Caspase 3 & Reverse primer & TTAGTGATAAAAATAGAGTTCTTTTGTGAG \\
\hline Caspase 9 & Forward primer & AGCCAGATGCTGTCCCATAC \\
\hline Caspase 9 & Reverse primer & CAGGAGACAAAACCTGGGA \\
\hline Caspase 8 & Forward primer & CTGGGAAGGATCGACGATTA \\
\hline Caspase 8 & Reverse primer & CATGTCCTGCATTTTGATGG \\
\hline GAPDH & Forward primer & GGCATTGCTCTCAATGACAA \\
\hline GAPDH & Reverse primer & TGTGAGGGAGATGCTCAGTG \\
\hline
\end{tabular}

To address whether differences in apoptosis profiles between influenza $\mathrm{A}$ and $\mathrm{B}$ strains depend on NF- $\kappa \mathrm{B}$ factor, the levels of NF- $\kappa \mathrm{B}$ versus its endogenous inhibitor, the $\mathrm{I} \kappa \mathrm{B}$ (inhibitor of kappa $\mathrm{B}$ ), and tumor necrosis factor alpha $(\mathrm{TNF} \alpha)$ which induced NF- $\kappa \mathrm{B}$ activation [37] were evaluated throughout $\mathrm{H} 1 \mathrm{~N} 1$ and $\mathrm{H} 3 \mathrm{~N} 2$ and INF B virus infection, respectively, and compared between all strains (Tables 2, 3, and 4). The analysis of the TNF $\alpha$ and $\mathrm{I} \kappa \mathrm{B}$ protein levels revealed that infection with INF B induced TNF $\alpha$ and $\mathrm{I} \kappa \mathrm{B}$ ratio earlier at $16 \mathrm{hpi}$, higher than that observed in mock infection in both cell lines (Tables 2, 3, and 4).

Regarding $\mathrm{H} 1 \mathrm{~N} 1$ and $\mathrm{H} 3 \mathrm{~N} 2$ infection, respectively, although the maximum value for $\mathrm{TNF} \alpha$ and $\mathrm{I} \kappa \mathrm{B}$ ratio was also observed at 16 and $48 \mathrm{hpi}$, it remained always higher than that detected for $\mathrm{H} 1 \mathrm{~N} 1$ and $\mathrm{H} 3 \mathrm{~N} 2$, respectively, at 16 and $48 \mathrm{hpi}$, or for mock infection, during 16 and $48 \mathrm{hpi}$. This 


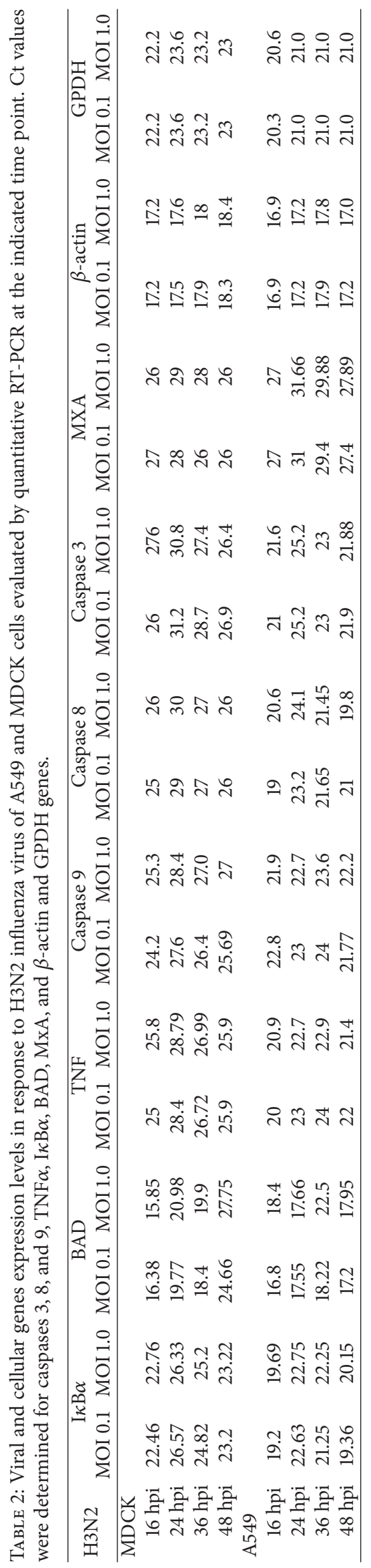




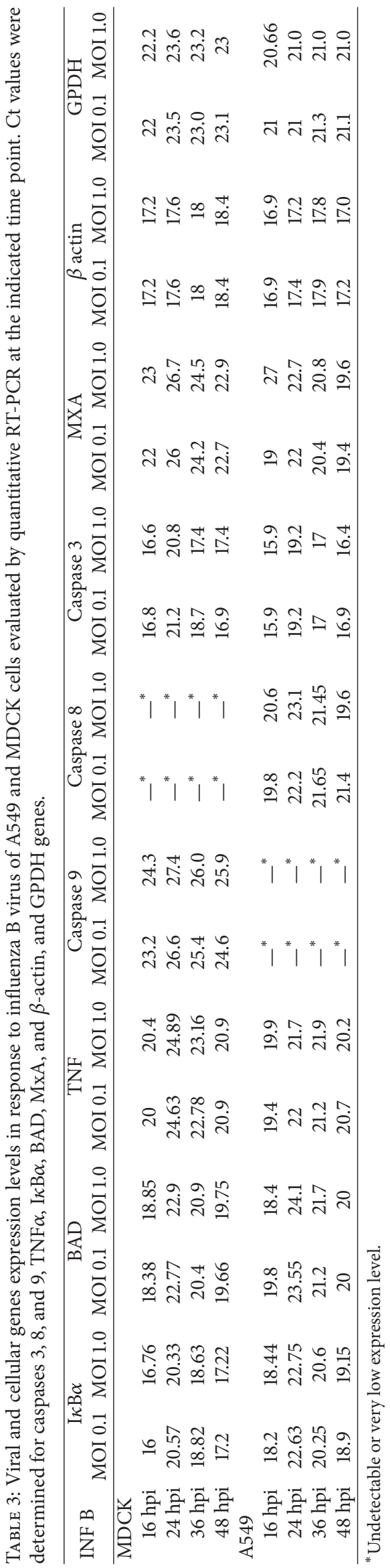




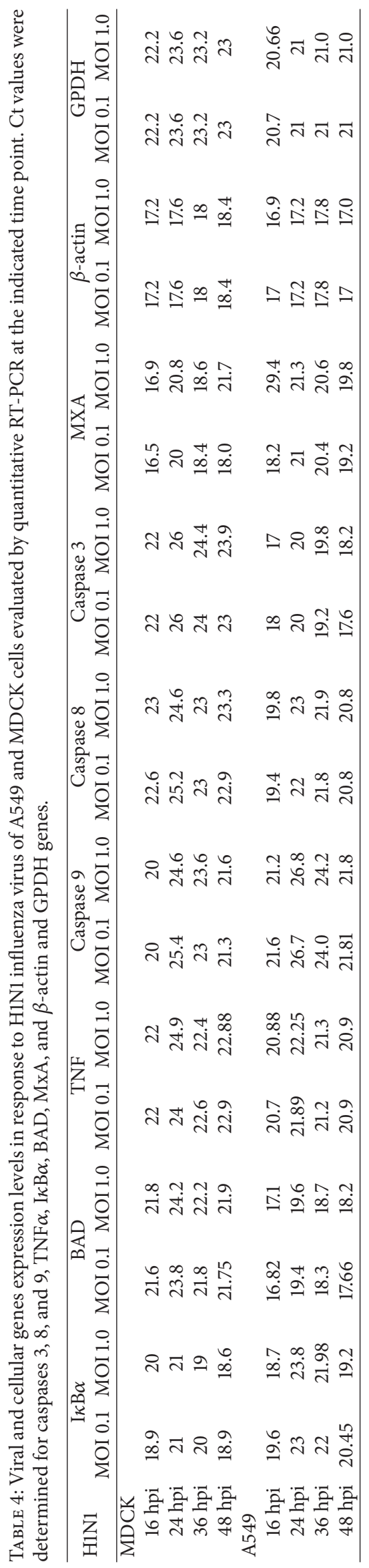


may be explained by the continuous increase of $\mathrm{I} \kappa \mathrm{B} \alpha$ protein levels throughout INF B infection (Tables 2, 3 and 4). To confirm whether influenza A or influenza B strains mediated increase in $\mathrm{TNF} \alpha / \mathrm{I} \kappa \mathrm{B}$ ratio reflects the enhancement in NF$\kappa \mathrm{B}$ activity, the transcriptional activity of $\mathrm{NF}-\kappa \mathrm{B}$ was studied throughout $\mathrm{H} 1 \mathrm{~N} 1$ and $\mathrm{H} 3 \mathrm{~N} 2$ and INF B and mock infection periods. From the upper data, these results revealed that NF- $\kappa \mathrm{B}$ survival pathway activation might be the responsible factor for the distinct apoptosis profiles induced by $\mathrm{H} 1 \mathrm{~N} 1$ and H3N2 and INF B infection. Curiously, in this cellular context, NF- $\kappa \mathrm{B}$ might be activated by mechanisms dependent on the regulation of $\mathrm{I} \kappa \mathrm{B}$ protein levels.

\section{Discussion}

Viruses have evolved multiple and complex strategies to subvert and evade the host immune-response to ensure their own replication and survival $[31,38,39]$.

Although the death receptor mediated apoptosis pathway induced by influenza infection has been extensively studied [40-42], little is known about the differences in the kinetics and pathways of apoptosis induction in influenza A and B viruses infections. Early in infection, viral NS1 binds to the PI3K subunit $\mathrm{p} 85$ and activates the kinase [23].

This results in activation of Akt/PKB via phosphorylation by pyruvate dehydrogenase kinase and the mammalian target of rapamycin complex 2 [43].

Activated Akt negatively regulates proapoptotic factors [caspase 3, caspase 9, Bcl-2 associated death promoter (BAD), and GSK-3] and thereby suppresses early apoptosis [44].

At later stages of infection, the virus-induced NF- $\kappa \mathrm{B}$ activation leads to the expression of proapoptotic factors (Fas, FasL, and TRAIL), thereby, to caspase induction, resulting in increased RNP export [28].

During productive virus infection, the proapoptotic factors TRAIL and FasL are expressed in an NF- $\kappa \mathrm{B}$-dependent manner.

The classical mechanism of NF- $\kappa \mathrm{B}$ activation includes activation of IKK, which phosphorylates the inhibitor of $\mathrm{NF}-\kappa \mathrm{B}$ and $\mathrm{I} \kappa \mathrm{B}$ and targets the protein for subsequent degradation. This leads to the release and migration of the transcriptionally active NF- $\kappa \mathrm{B}$ factors, such as $\mathrm{p} 65$ or $\mathrm{p} 50$, to the nucleus [43].

The early induction of extrinsic pathway of apoptosis by influenza B infection, detected by the increase in the activity of the initiator caspase 8 , reveals the inability of influenza B strain to avoid cell death through this pathway.

Curiously, the extrinsic pathway of apoptosis has been previously associated with the innate antiviral cell response that leads to the production of interferon (IFN) $\alpha$, IFN $\beta$, and cytokines capable of inducing apoptosis by the TNF-related apoptosis ligand (TRAIL) pathway, which in turn trigger the extrinsic pathway of apoptosis by the cell death receptor pathway $[17,45]$.

In contrast, the induction of the extrinsic apoptosis pathway was only observed for influenza A infection at 16 hpi, reflecting the ability of the influenza A virus to counteract with this antiviral cell response.
The PI3K/Akt pathway, one of the pathways hijacked by the NS1 protein of influenza A virus, was already shown to be responsible for a delay in induction of apoptosis in the host cells [46].

The PI3K/Akt pathway was activated in a similar extent by the influenza A and B viruses strain infection. However, influenza A strain was able to induce a second activation of this pathway later throughout the infection period ( $24 \mathrm{hpi})$.

Although the initial activation of this pathway by influenza A strain could partially explain the delay in apoptosis induction of influenza A in comparison with influenza $\mathrm{B}$, additional mechanisms must be in place by influenza $\mathrm{A}$ in infected cells to block preactivated apoptosis and avoid cell loss $[3,5]$.

We have provided experimental evidences that influenza virus $\mathrm{H} 3 \mathrm{~N} 2$ induces an apoptotic response mediated by caspases activation for the host cells that is similar to but delayed compared with that induced by human influenza viruses including $\mathrm{H} 1 \mathrm{~N} 1$ and INF B.

Activated caspase 8 is able to cleave additional downstream caspases and also activate Bid; proapoptotic member of the $\mathrm{Bcl}-2$ proteins resulted in an efflux of cytochrome $\mathrm{c}$ into the cytoplasm [47].

The viral infection at higher MOI induced cleavage of procaspase 8 into intermediate p41-43 at the earlier stage of infection ( $24 \mathrm{hpi}$ ) followed by activation to its p18 active at 48 hpi using an antibody directed against the $\mathrm{N}$ terminal fragment of this protein [34].

NF- $\kappa \mathrm{B}$ activation has already been associated with the antiviral response of the influenza A infected cells $[45,48]$.

It is possible that $\mathrm{NF}-\kappa \mathrm{B}$ may also be required for influenza $A$ virus replication by activating the transcription of antiapoptotic factors [4, 49].

In fact, when comparing with influenza B strain, influenza A strain infection markedly increased the levels of the NF- $\kappa$ B downstream survival targets, including Bcl-XL and XIAP. However, the influenza A mediated effects were only associated with a delay in apoptosis induction, rather than within crease in apoptotic resistance of infected cells.

Although the differences observed in kinetics and pathways of induction of apoptosis between influenza $A$ and $B$ strain infections point to occur at the $\mathrm{I} \kappa \mathrm{B} / \mathrm{NF}-\kappa \mathrm{B}$ level, further studies are required to clarify the molecular mechanisms by which influenza $\mathrm{B}$ virus induces $\mathrm{I} \kappa \mathrm{B}$ accumulation.

A better understanding of the molecular mechanisms by which influenza A and B viruses regulate apoptosis in host cells have also the potential to uncover the networks of factors that may contribute to a successful influenza virus replication, crucial for the development of vaccines and antiviral drugs $[5,28]$.

4.1. Influenza $A$ and $B$ Viruses Differentially Modulate the Expression of $I \kappa B$ Protein Level. To analyze the differences on apoptosis regulatory mechanisms between $\mathrm{H} 1 \mathrm{N1}$ and $\mathrm{H} 3 \mathrm{~N} 2$ and INF B infection, namely, the involvement of $\mathrm{I} \kappa \mathrm{B}$ protein level activation in these events, the expression levels of survival downstream targets of $\mathrm{I} \kappa \mathrm{B}$ protein level, including proapoptotic BAD levels, were studied throughout the infection periods. 
RT-PCR showed that BAD levels are highly pronounced in INF B than in $\mathrm{H} 1 \mathrm{~N} 1$ and $\mathrm{H} 3 \mathrm{~N} 2$, respectively. In fact, at 16 hpi, INF B showed higher levels of BAD when compared with mock infection. The levels of BAD were expressed in lower levels when compared with those observed after $16 \mathrm{~h}$ of H1N1 and H3N2 infection. These findings suggest distinct regulatory networks of apoptosis between $\mathrm{H} 1 \mathrm{~N} 1$ and $\mathrm{H} 3 \mathrm{~N} 2$ and INF B infection, which might support the role of the prosurvival factor NF- $\kappa \mathrm{B}$ and its target genes in delaying apoptosis initiation and $\mathrm{CPE}$ in $\mathrm{H} 3 \mathrm{~N} 2$ infection compared with influenza B and H1N1 infection, respectively.

Influenza virus-induced cytopathic effect (CPE) and cell death are inhibited in BAD deficient cells. Influenza virus killing of host cells is known to occur through the activation of the apoptotic signaling pathway $[50,51]$.

BAD is an important regulator of antiapoptotic Bcl-2 and $\mathrm{Bcl}-\mathrm{xL}$ proteins. Its blockage of $\mathrm{Bcl}-2$ and $\mathrm{Bcl}-\mathrm{xL}$ defines the fate of the host cell toward apoptosis [51].

Infected cells were examined visually for demonstration of cytopathic effect (CPE), which phenotypically manifests as rounding up and detachment of infected cells as well as abnormal cellular structural morphology BAD knockdown in A549 cells reduced influenza virus replication of different virus subtypes.

A number of studies have reported the important role apoptosis plays in promoting efficient influenza virus replication $[39,42]$.

The delayed onset of apoptosis by H3N2 influenza virus infected respiratory epithelial cells A549 may be a mechanism for the influenza viruses to have more prolonged replication within the human respiratory tract, and this may contribute to the pathogenesis of human disease [52].

In contrast to [42] the delayed CPE in the H1N2 infected cells might result from decrease of cell death rate, cytochrome c release, and apoptosome formation as compared to those of H1N1 and H3N2 infected cells.

Our study also showed that the considerable MxA expression was found in influenza A and B virus and infected A549 and MDCK II cells at low dose of the virus.

MxA mRNAs were induced in the infected A549 cells in a dose dependent manner, correlating with the replication of influenza A and B viruses in the cell. Activation of the cellular antiviral defense by MxA expression decreases virus replication at early time of infection which had not significant impact on final virus titers. The result suggests a role for IFN response in the replication of influenza A and B viruses that may provide some degree of host resistance in the early stages of infection. In contrast to MDCK II, the A549 cells are IFN-competent cells, and MxA is upregulated in these cells while the protein is either downregulated or even undetectable in MDCK II cell in response to influenza A and B infection. Thus, an insufficient antiviral defense in MDCK II cells promotes efficient influenza $A$ and $B$ viruses replication which is controlled in part by the IFN response. Taken together, the results demonstrated that the permissively of noncompeting IFN MDCK II cells for influenza A and B viruses is comparable with A549 cells; however, MDCK II cells are not target tissue that respond to the infection. These data revealed that the sensitivity of human alveolar epithelial cells to influenza A and B viruses induced apoptosis signaling via intrinsic and extrinsic pathways in parallel, and the induction was associated with viral infection in a dose dependent manner.

In conclusion, influenza viruses afflict millions of people each year and cause serious medical complications. Because of the high genetic variability of influenza viruses, the development of effective vaccines against pandemic influenza is still an ongoing challenge. In addition, although all H1N1 and $\mathrm{H} 3 \mathrm{~N} 2$, respectively, prefer initially to enhance the intrinsic pathway, as determined by higher caspase 9 activity in MDCK II cells compared to caspase 8 activity and vice versa in A549 cells at different MOI, INF B prefer extrinsic pathway according to significantly low or undetectable caspase 9 activity and high activity of caspase 8 in A549 cell line but also can choose intrinsic pathway as determined by significant low or undetectable caspase 8 activity and high caspase 9 activity in MDCK II cells at different MOI.

\section{Abbreviations}

$\begin{array}{ll}\text { Ct: } & \text { Threshold level } \\ \text { CPE: } & \text { Cytopathogenic effect } \\ \text { MOI: } & \text { Multiplicity of infection } \\ \text { hpi: } & \text { Hour postinfection }\end{array}$

MDCK: Madin-Darby canine kidney cell.

\section{Conflict of Interests}

The authors declare that there is no conflict of interests regarding the publication of this paper.

\section{Acknowledgments}

The authors would like to thank Dr. Amany El Gohary, Ph.D., Head of the Virology Departments, Central Public Health Labs (CPHL), for her efforts and Dr. Amer Sayed Ahmed and Dr. Shimaa Ibrahim in Molecular Biology and Virus Isolation Units in CPHL for their great efforts and for viruses and cell lines supports.

\section{References}

[1] C. Sweet and H. Smith, "Pathogenicity of influenza virus," Microbiological Reviews, vol. 44, no. 2, pp. 303-330, 1980.

[2] G. E. Price, H. Smith, and C. Sweet, "Differential induction of cytotoxicity and apoptosis by influenza virus strains of differing virulence," Journal of General Virology, vol. 78, no. 11, pp. 28212829, 1997.

[3] S. F. Baker, A. Nogales, C. Finch et al., "Influenza A and B virus intertypic reassortment through compatible viral packaging signals," Journal of Virology, vol. 88, no. 18, pp. 10778-10791, 2014.

[4] S. Ludwig and O. Planz, "Influenza viruses and the NF- $\kappa$ B signaling pathway-towards a novel concept of antiviral therapy," Biological Chemistry, vol. 389, no. 10, pp. 1307-1312, 2008.

[5] L. A. Santos, S. Solá, C. M. P. Rodrigues, and H. R. de Andrade, "Distinct kinetics and pathways of apoptosis in influenza A and 
B virus infection," Virus Research Journal, vol. 205, pp. 33-40, 2015.

[6] H. Rebelo de Andrade, A. Diniz, and F. Froes, Gripe, Sociedade Portuguesa de Pneumologia, Lisboa, Portugal, 2003.

[7] B. N. Fields, D. M. Knipe, and P. M. Howley, Fields Virology, vol. 2, Wolters Kluwer Health/Lippincott Williams \& Wilkins, Philadelphia, Pa, USA, London, UK, 5th edition, 2007.

[8] T. Takizawa, S. Matsukawa, Y. Higuchi, S. Nakamura, Y. Nakanishi, and R. Fukuda, "Induction of programmed cell death (apoptosis) by influenza virus infection in tissue culture cells," Journal of General Virology, vol. 74, no. 11, pp. 2347-2355, 1993.

[9] P. Gaur, A. Munjhal, and S. K. Lal, "Influenza virus and cell signaling pathways," Medical Science Monitor, vol. 17, no. 6, pp. RA148-RA154, 2011.

[10] R. König, S. Stertz, Y. Zhou et al., "Human host factors required for influenza virus replication," Nature, vol. 463, no. 7282, pp. 813-817, 2010.

[11] R. M. Krug, W. Yuan, D. L. Noah, and A. G. Latham, "Intracellular warfare between human influenza viruses and human cells: the roles of the viral NS1 protein," Virology, vol. 309, no. 2, pp. 181-189, 2003.

[12] V. S. Hinshaw, C. W. Olsen, N. R. Dybdahl Sissoko, and D. Evans, "Apoptosis: a mechanism of cell killing by influenza A and B viruses," Journal of Virology, vol. 68, no. 6, pp. 3667-3673, 1994.

[13] S. Ludwig, S. Pleschka, O. Planz, and T. Wolff, "Ringing the alarm bells: signalling and apoptosis in influenza virus infected cells," Cellular Microbiology, vol. 8, no. 3, pp. 375-386, 2006.

[14] M. C. Kleinschmidt, M. Michaelis, H. Ogbomo, H.-W. Doerr, and J. Cinatl Jr., "Inhibition of apoptosis prevents West Nile virus induced cell death," BMC Microbiology, vol. 7, article 49, 8 pages, 2007.

[15] Q. Gao, Z. Wang, Z. Liu et al., "A cell-based high-throughput approach to identify inhibitors of influenza A virus," Acta Pharmaceutica Sinica B, vol. 4, no. 4, pp. 301-306, 2014.

[16] C. R. Baskin, A. García-Sastre, T. M. Tumpey et al., "Integration of clinical data, pathology, and cDNA microarrays in influenza virus-infected pigtailed macaques (Macaca nemestrina)," Journal of Virology, vol. 78, no. 19, pp. 10420-10432, 2004.

[17] C. Cillóniz, K. Shinya, X. Peng et al., "Lethal influenza virus infection in macaques is associated with early dysregulation of inflammatory related genes," PLoS Pathogens, vol. 5, no. 10, Article ID e1000604, 2009.

[18] S. Shahsavandi, M. M. Ebrahimi, K. Sadeghi, S. Z. Mosavi, and A. Mohammadi, "Dose- and time-dependent apoptosis induced by avian H9N2 influenza virus in human cells," BioMed Research International, vol. 2013, Article ID 524165, 7 pages, 2013.

[19] L. Duprez, E. Wirawan, T. V. Berghe, and P. Vandenabeele, "Major cell death pathways at a glance," Microbes and Infection, vol. 11, no. 13, pp. 1050-1062, 2009.

[20] B. Levine, S. Sinha, and G. Kroemer, "Bcl-2 family members: dual regulators of apoptosis and autophagy," Autophagy, vol. 4, no. 5, pp. 600-606, 2008.

[21] A. Autret and S. J. Martin, "Emerging role for members of the Bcl-2 family of mitochondrial morphogenesis," Molecular Cell, vol. 36, no. 3, pp. 355-363, 2009.

[22] C. Chen, L. C. Edelstein, and C. Gélinas, “The Rel/NF- $\kappa$ b family directly activates expression of the apoptosis inhibitor BCl$\mathrm{x}(\mathrm{L})$, , Molecular and Cellular Biology, vol. 20, no. 8, pp. 26872695, 2000.
[23] B.-J. Kroesen, N. Teteloshvili, K. Smigielska-Czepiel et al., "Immuno-miRs: critical regulators of T-cell development, function and ageing," Immunology, vol. 144, no. 1, pp. 1-10, 2015.

[24] C. Sweet, S. J. Morris, M. A. Mohsin, and H. Smith, "Mechanisms of differential induction of apoptosis by H3N2 and H1N1 influenza viruses," International Congress Series, vol. 1219, pp. 573-579, 2001.

[25] E. Yang, J. Zha, J. Jockel, L. H. Boise, C. B. Thompson, and S. J. Korsmeyer, "Bad, a heterodimeric partner for Bcl- $\mathrm{x}_{\mathrm{L}}$ and $\mathrm{Bcl}-2$, displaces bax and promotes cell death," Cell, vol. 80, no. 2, pp. 285-291, 1995.

[26] J. Zha, H. Harada, K. Osipov, J. Jockel, G. Waksman, and S. J. Korsmeyer, "BH3 domain of $\mathrm{BAD}$ is required for hetero dimerization with BCL-XL and pro-apoptotic activity," The Journal of Biological Chemistry, vol. 272, no. 39, pp. 24101-24104, 1997.

[27] A. S. Baldwin Jr., "The NF-kappa B and I kappa B proteins: new discoveries and insights," Annual Review of Immunology, vol. 14, pp. 649-683, 1996.

[28] J. M. Hill, C. Clement, Y. Zhao, and W. J. Lukiw, "Induction of the pro-inflammatory NF-kB-sensitive miRNA-146a by human neurotrophic viruses," Frontiers in Microbiology, vol. 6, no. 43, 2015.

[29] S. D. Catz and J. L. Johnson, "Transcriptional regulation of bcl2 by nuclear factor $\kappa \mathrm{B}$ and its significance in prostate cancer," Oncogene, vol. 20, no. 50, pp. 7342-7351, 2001.

[30] B.-C. Ho, I.-S. Yu, L.-F. Lu et al., "Inhibition of miR-146a prevents enterovirus-induced death by restoring the production of type I interferon," Nature Communications, vol. 5, no. 3344, pp. 1-14, 2014.

[31] J. M. Hill, Y. Zhao, C. Clement, D. M. Neumann, and W. J. Lukiw, "HSV-1infectionofhuman brain cells induces miRNA-146a and Alzheimer type inflammatory signaling," Neuroreport, vol. 20, pp. 1500-1505, 2009.

[32] R. Kim, "Unknotting the roles of Bcl-2 and Bcl-xL in cell death," Biochemical and Biophysical Research Communications, vol. 333, no. 2, pp. 336-343, 2005.

[33] W. Yuan, J. M. Aramini, G. T. Montelione, and R. M. Krug, "Structural basis for ubiquitin like ISG 15 protein binding to the NS1 protein of influenza B virus: a protein protein interaction function that is not shared by the corresponding $\mathrm{N}$ terminal domain of the NS1 protein of influenza A virus," Virology, vol. 304, no. 2, pp. 291-301, 2002.

[34] S. Shahsavandi, M. M. Ebrahimi, A. Mohammadi, and N. Zarrin Lebas, "Impact of chicken-origin cells on adaptation of a low pathogenic influenza virus," Cytotechnology, vol. 65, no. 3, pp. 419-424, 2013.

[35] M. J. Allen and N. Rushton, "Use of the CytoTox $96^{\mathrm{TM}}$ Assay in routine biocompatibility testing in vitro," Promega Notes, vol. 45 , pp. 7-10, 1994.

[36] S. Ludwig, "Targeting cell signalling pathways to fight the flu: towards a paradigm change in anti-influenza therapy," Journal of Antimicrobial Chemotherapy, vol. 64, no. 1, pp. 1-4, 2009.

[37] K. Blackwell, L. Zhang, L. M. Workman, A. T. Ting, K. Iwai, and H. Habelhah, "Two coordinated mechanisms underlie tumor necrosis factor $\alpha$ a-induced immediate and delayed $\mathrm{I} \kappa \mathrm{B}$ kinase activation," Molecular and Cellular Biology, vol. 33, no. 10, pp. 1901-1915, 2013.

[38] N. Kodaman, R. S. Sobota, R. Mera, B. G. Schneider, and S. M. Williams, "Disrupted human-pathogen co-evolution: a model for disease," Frontiers in Genetics, vol. 5, article 290, 12 pages, 2014. 
[39] Z. Xing, R. Harper, J. Anunciacion et al., "Host immune and apoptotic responses to avian influenza virus H9N2 in human tracheobronchial epithelial cells," American Journal of Respiratory Cell and Molecular Biology, vol. 44, no. 1, pp. 24-33, 2010.

[40] T. Takizawa, C. Tatematsu, K. Ohashi, and Y. Nakanishi, "Recruitment of apoptotic cysteine proteases (caspases) in influenza virus-induced cell death," Microbiology and Immunology, vol. 43, no. 3, pp. 245-252, 1999.

[41] N. Wada, M. Matsumura, Y. Ohba, N. Kobayashi, T. Takizawa, and Y. Nakanishi, "Transcription stimulation of the Fasencoding gene by nuclear factor for interleukin- 6 expression upon influenza virus infection," The Journal of Biological Chemistry, vol. 270, no. 30, pp. 18007-18012, 1995.

[42] M. Uiprasertkul, R. Kitphati, P. Puthavathana et al., "Apoptosis and pathogenesis of avian influenza A (H5N1) virus in humans," Emerging Infectious Diseases, vol. 13, no. 5, pp. 708-712, 2007.

[43] S. Herold, S. Ludwig, S. Pleschka, and T. Wolff, "Apoptosis signaling in influenza virus propagation, innate host defense, and lung injury," Journal of Leukocyte Biology, vol. 92, no. 1, pp. 75-82, 2012.

[44] X. Lu, A. Masic, Y. Li, Y. Shin, Q. Liu, and Y. Zhou, "The PI3K/Akt pathway inhibits influenza A virus-induced Baxmediated apoptosis by negatively regulating the JNK pathway via ASK1," Journal of General Virology, vol. 91, no. 6, pp. 14391449, 2010.

[45] D. Mulbauer, J. Dzieciolowski, M. Hardt et al., "Influenza virus induced caspase dependent enlargement of nuclear pores promotes nuclear export of viral ribonucleoprotein complexes," Journal of Virology, vol. 89, no. 21, pp. 1-36, 2015.

[46] Y.-K. Shin, Y. Li, Q. Liu, D. H. Anderson, L. A. Babiuk, and Y. Zhou, "SH3 binding motif 1 in influenza A virus NS1 protein is essential for PI3K/Akt signaling pathway activation," Journal of Virology, vol. 81, no. 23, pp. 12730-12739, 2007.

[47] E. W. A. Brydon, S. J. Morris, and C. Sweet, "Role of apoptosis and cytokines in influenza virus morbidity," FEMS Microbiology Reviews, vol. 29, no. 4, pp. 837-850, 2005.

[48] C. Wang, L. Gao, Y. Jin, C. J. Cardona, and Z. Xing, "Regulation of host responses and viral replication by the mitogenactivated protein kinases in intestinal epithelial cells infected with Enterovirus 71," Virus Research, vol. 197, pp. 75-84, 2015.

[49] S. D. Shapira, I. Gat-Viks, B. O. V. Shum et al., "A physical and regulatory map of host-influenza interactions reveals pathways in H1N1 infection," Cell, vol. 139, no. 7, pp. 1255-1267, 2009.

[50] J. E. McLean, E. Datan, D. Matassov, and Z. F. Zakeri, "Lack of Bax prevents influenza A virus-induced apoptosis and causes diminished viral replication," Journal of Virology, vol. 83, no. 16, pp. 8233-8246, 2009.

[51] A. T. Tran, J. P. Cortens, Q. Du, J. A. Wilkins, and K. M. Coombs, "Influenza virus induces apoptosis via BAD-mediated mitochondrial dysregulation," Journal of Virology, vol. 87, no. 2, pp. 1049-1060, 2013.

[52] K. M. Yuen, R. W. Y. Chan, C. K. P. Mok et al., "Differential onset of apoptosis in avian influenza $\mathrm{H} 5 \mathrm{~N} 1$ and seasonal $\mathrm{H} 1 \mathrm{~N} 1$ virus infected human bronchial and alveolar epithelial cells: an in vitro and ex vivo study," Influenza and Other Respiratory Viruses, vol. 5, no. 1, pp. 437-438, 2011. 

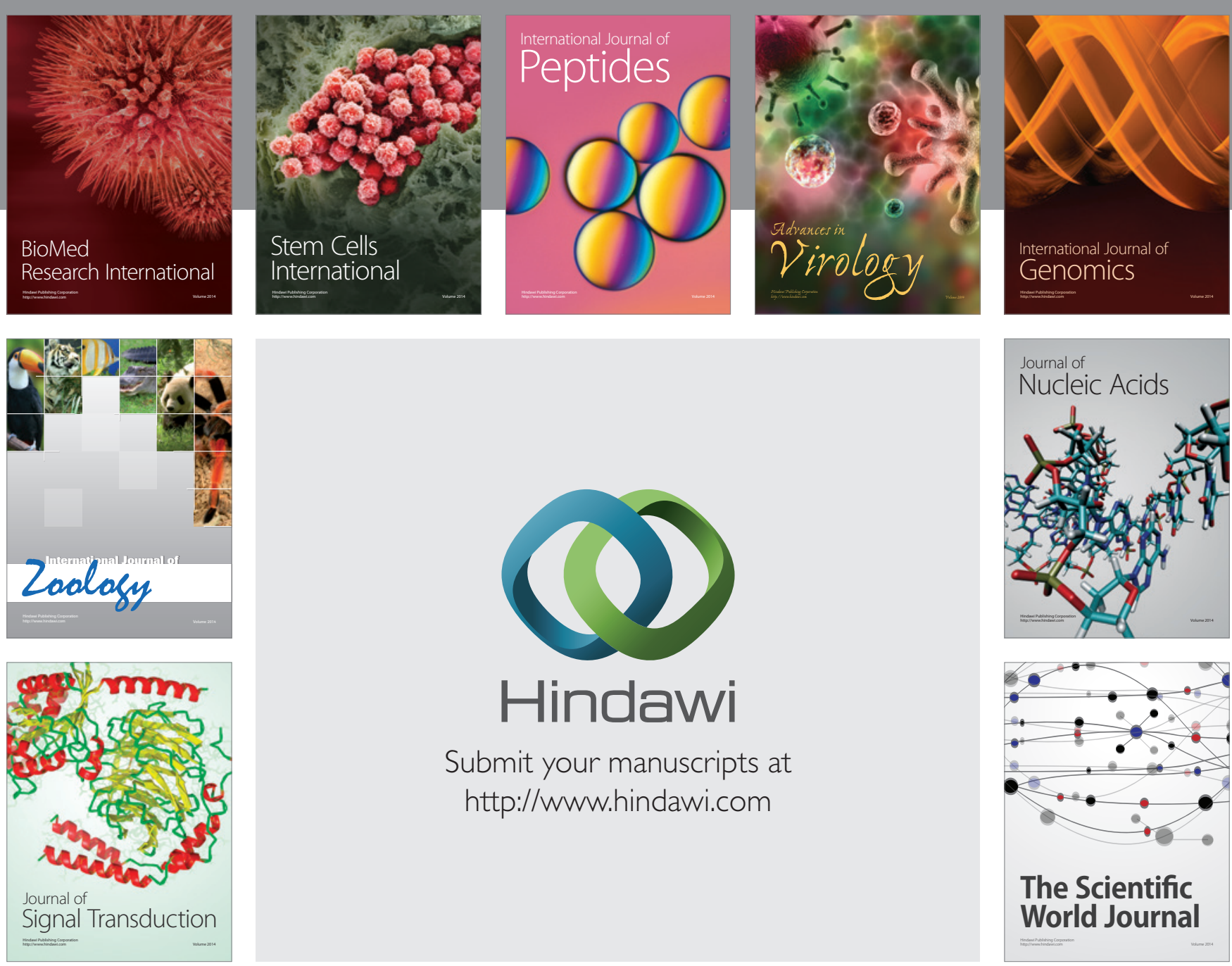

Submit your manuscripts at

http://www.hindawi.com
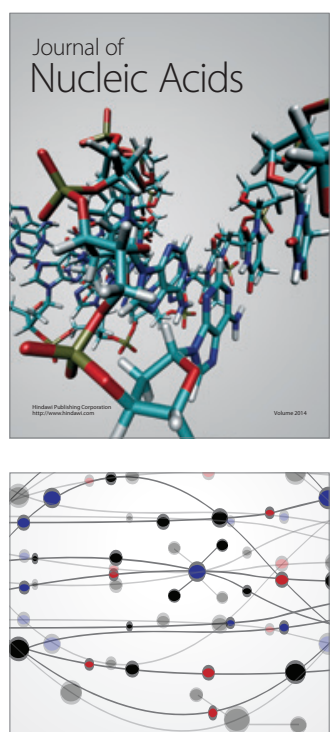

The Scientific World Journal
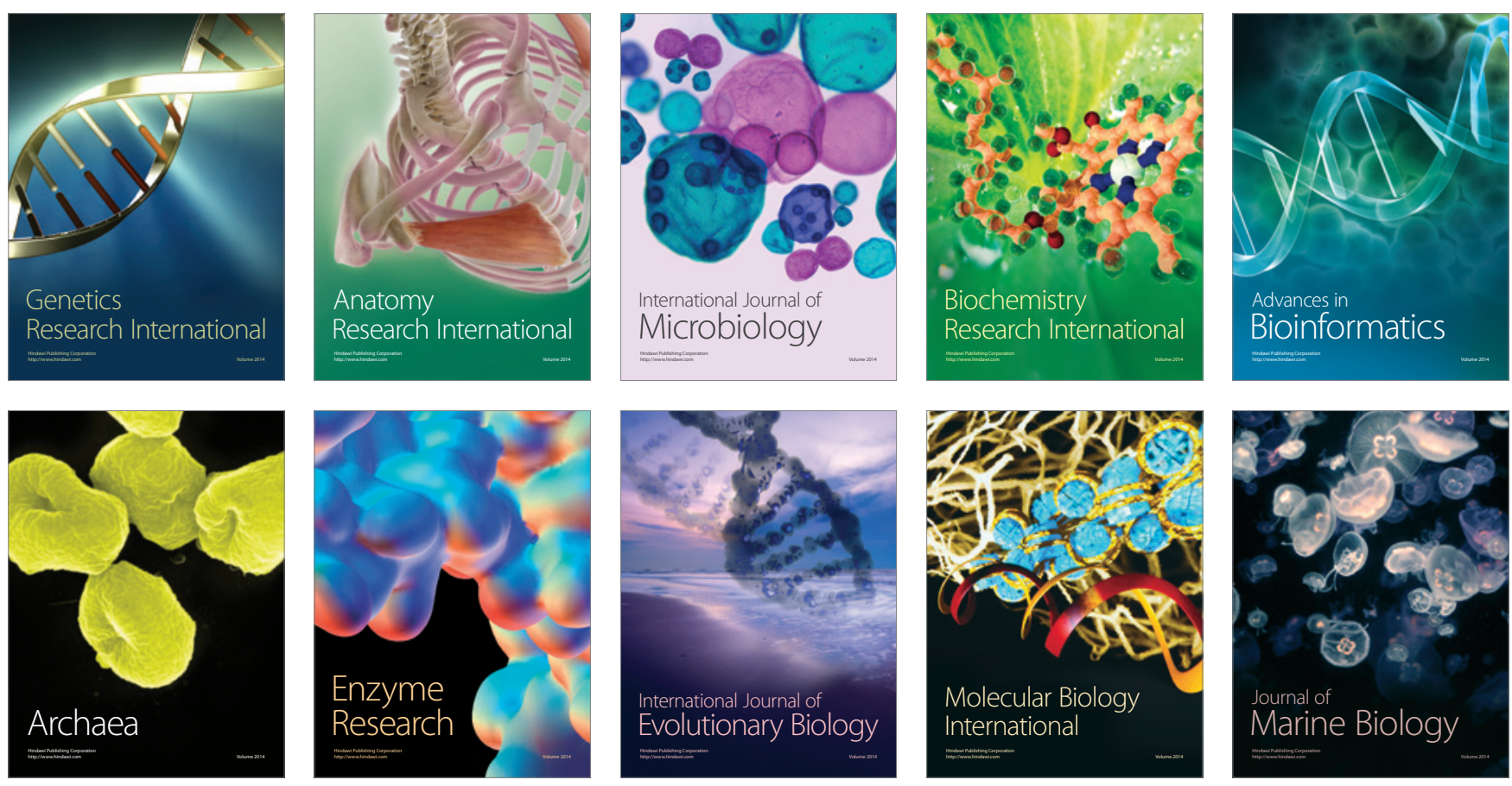